\title{
ANALISIS USAHA MINYAK SEREH DALAM MENIGKATKAN PRODUKSI KECAMATAN MASAMBA KABUPATEN LUWU UTARA
}

\author{
RAHAYU NINGSI, MUH. AMIR ANAS, HAPID
}

\begin{abstract}
ABSTRAK
Produksi minyak sereh dikabupaten luwu utara merupakan salah satu produksi di Indonesia,hal ini dikarenakan kabupaten luwu utara merupakan tempat yang cocok untuk pertumbuhan tanaman sereh,minyak sereh disolasi dari daun sereh wangi. Selama ini,minyak sereh diekspor keluar daerah dalam bentuk minyak sereh murni sehingga kurang mendatangkan devisa Negara.sehingga diperlukan usaha untuk meningkatkan nilai guna dari minyak sereh.pada penelitian ini akan dilakukan pemisahan komponen geraniol dari minyak sereh.

Penelitian tentang Analisis Usaha Minyak Sereh Dalam Menigkatkan Produksi Kecamatan Masamba Kabupaten Luwu Utara bertujuan untuk mengetahui uasaha minyak sereh terhadap peningkatan produksi minyak sereh dikecamatan Masamba Kabupaten luwu utara dan hubungannya dengan perkembangan bahan baku pada usaha minyak sereh di kecamatan masamba.

Adapun metode analisis yang digunakan adalah analisis regresi linier sederhana.metode ini dimaksudkan untuk mengetahui hubungan variabel dependen dengan variabel indevenden.hubungan antara variabel pada regresi linier sederhana ini dapat berupa hubungan positif ataupun hu ungan positif.

Dari hasil penelitian menunjukkan jumlah produksi minyak sereh meningkat seiring dengan meningkatnya jumlah tenaga kerja dan jumlah bahan baku tetap. Serta menunjukkan pula bahwa sistem pemesanan dan penyediaan bahan baku yang dijalankan perusahaan ini tepat, sehingga masih di butuhkan sistem pengendalian yang lebih baik untu menunjang kelancaran proses produksi.
\end{abstract}

Kata kunci: tenaga kerja, bahan baku, peningkatan produksi, minyak sereh.

\section{Pendahuluan}

\section{Latar belakang}

Produksi minyak sereh dikabupaten luwu utara merupakan salah satu produksi di Indonesia,hal ini dikarenakan kabupaten luwu utara merupakan tempat yang cocok untuk pertumbuhan tanaman sereh,minyak sereh disolasi dari daun sereh wangi. Selama ini,minyak sereh diekspor keluar daerah dalam bentuk minyak sereh murni sehingga kurang mendatangkan devisa Negara.sehingga diperlukan usaha untuk meningkatkan nilai guna dari 
minyak sereh.pada penelitian ini akan dilakukan pemisahan komponen geraniol dari minyak sereh.Geraniol memiliki manfaat yang luas dibidang kosmetik,peternakan dan kesehatan.

Minyak sereh dapat disolasi dari daun sereh wangi menggunakan metode destilasi uap. Destilat miyak sereh diekstraksi dengan eter untuk memisahkan dari air.untuk meningkatkan kandungan geraniolnya,minyak sereh dihidrolisis dengan larutan $\mathrm{NaOH}$ dalam etanol selama 1 jam untuk menghidrolisis geranil asetat menjadi geraniol.Identifikasih senyawa geraniol dilakukan dengan menggunakan kromatografi gas-spektrommetri massa (GC-MS).

Daun sereh wangi seberat $10 \mathrm{~kg}$ menghasilkan minyak sereh sebanyak 42,5 $\mathrm{mL}(0,37 \%)$ dengan warna kuning bening mengkilat bau khas sereh dan memiliki indeks bias sebesar 1,4755.Data kromatogram GC minyak sereh menunjukkan kandungan geraniol sebanyak 65,34\%.pengkayaan geraniol menggunakan larutan $\mathrm{NaOH}$ dalam etanol mengakibatkan terjadinya reaksi hidrolisis geranil asetat menjadi geraniol yang meningkatkan kandungan geraniol menjadi $81,96 \%$.

Dalam menanggulangi hama ini, petani telah melakukan pengendalian secara alami diantaranya dengan pembungkusan buah,pengurangan tanaman dengan jarring plastik,pengasapan disekitar pohon dan lainnya.Usaha ini memugkinkan untuk luasan lahan yang luasnya puluhan hektar.pengendalian lain yang telah dilakukan adalah pemandulan jantan,kimiawi dan memakai perangkap dengan menggunakan atraktan/penarik.

Setelah dipaparkan latar belakang tersebut diatas,maka penulis tertarik dan merasa perlu untuk membahas dalam penelitian dengan judul Analisis usaha minyak sereh dalam meningkatkan produksi di kecamatan masamba kabupaten luwu utara. Masalah penelitian ini adalah apakah factor bahan baku dan tenaga kerja dapat meningkatkan produksi minyak sereh? Tujuan penelitian adalah untuk mengetahui uasaha minyak sereh terhadap peningkatan produksi minyak sereh dikecamatan Masmba Kabupaten luwu utara.

\section{Metode Penelitian}

Lokasi penelitian

Penelitian ini dilaksanakan pada usaha minyak sereh di kecamatan masamba kabupaten luwu utara sedangkan waktu penelitian dilaksanakan pada bulan maret sampai dengan bulan mei 2011

Jenis dan sumber data

(a) Data primer,yaitu data yang diperoleh secara langsung melalui opservasi dan wawancara karyawan perusahaan maupun dari responden atau konsumen.

(b) Data sekunder,yaitu data yang diperoleh dari laporan laporan dan dokumen dokumen perusahaan sepertu data serta referensi yang ada kaitannya dengan penelitian.

Metode pengumpulan data.

Metode pengumpulan data dalam penenlitian ini adalah: (a) Observasi,yaitu dengan melakukan pengamatan secara langsung terhadap obyek yang diteliti, (b) Interview,yaitu 
dengan melakukan serangkaian tanyah jawab kepada pimpinan perusahaan,serta karyawan yang ada relevanisnya dengan obyek penelitian ini.

Metode analisis

Metode analisis data yang digunakan dalam penelitian ini adalah analisis regresi linier sederhana.metode ini dimaksudkan untuk mengetahui hubungan variabel dependen dengan variabel indevenden. Hubungan antara variabel pada regresi linier sederhana ini dapat berupa hubungan positif ataupun hu ungan positif. Hubungan positif terjadi apabila hubungan antara dua variabel (dependen dan independen) sama sama naik.sedangkan hubungan negative terjadi bila variabel yang mempengaruhi naik dan variabel yang dipengaruhi turun,maka penulis menggunakan analisa regresi linier berganda dengan formula sebagai berikut (Supranto,1996:5051).

$$
\begin{aligned}
& \mathrm{Y}=\mathrm{b}_{0}+\mathrm{b}_{1}+\mathrm{b}_{2} \mathrm{X}_{2} \\
& \text { Dimana } \mathrm{Y}=\text { Jumlah produksi minyak sereh } \\
& \mathrm{X}_{1}=\text { Bahan baku } \mathrm{X}_{2}=\text { Tenaga kerja } \mathrm{b}_{0} \\
& \text { =Nilai Konstanta }
\end{aligned}
$$$$
b_{1} \text { dan } b_{2}=\text { Koefisien Regresi }
$$

\section{Hasil Penelitian Dan Pembahasan}

Deskripsi hasil penelitian

Gambaran umum kecamatan masamba

Jika ditinjau dari segi letak geografis kecamatan masamba merupakan salah satu kecamatan yang sangat potensial dalam hal pengembangan industri, khususnya industri kecil.

Wilayah kecamatan masamba yang berkedudukan pada kabupaten luwu utara ini, menyebabkan arus perekonomian yang cukup lancer sekaligus meningkatkan pendapatan masyarakat, khususnya pada sector industry kecil

Dengan demikian maka dapat disimpulkan bahwa letak geografis wilayah kecamatan masamba merupakan salah satu daerah yang mendapat perhatian dalam upaya meningkatkan subsector industry kecil dengan melalui beberapa kebijaksanaan pemerintah.

Terlepas dari masalah-masalah yang telah dikemukakan diatas, maka dengan dekatnya kecamatan masamba dari pusat ibukota ini menyebabkan tidak sulit untuk memasarkan hasil industrinya sehingga dapat teratasi daru resiko penumpukan hasilhasil industri.

Potensi social ekonomi

Dalam upaya untuk meningkatkan pendapatan masyarakat, khususnya bagi perajin industry minyak sereh dengan melalui pelatihan-pelatihan, maka selain didukung oleh geografis suatu daerah, maka juga harus di dukung oleh beberapa factor lainnya.

a. Luas wilayah

Untuk mengukur tinggi rendahnya suatu daerah, maka salah satu variabel yang sangat berpengaruh adalah mengenai luas wilayah. Dalam kaitannya dalam hal tersebut maka 
kecamatan masamba, adalah merupakan salah satu kecamatan yang mempunyai wilayah sekitar 1068,85 $\mathrm{km}^{2}$ yang cukup luas untuk pengembangan industry kecil.

b. Penduduk

Secara teoritis kita mengenal beberapa macam factor-faktor produksi, salah satu diantaranya adalah tenega kerja (penduduk), artinya dalam memproduksi suatu barang maka dibutuhkan tenaga kerja yang produktif, sehingga sesuatu yang dihasilkan mempunyai produktifitas yang baik.

Dalam kaitannya dengan upaya untuk meningkatkan produktivitas para pengrajin industry kecil, maka dengan melalui pola pemberian pelatihan semakin dituntut tenaga kerja yang produktivitasnya, baik untuk memanfaatkan sarana produksi secara optimal. Dengan adanya penduduk, maka akan mendukung pengembangan setiap sector ekonomi khususnya pengembangan produksi minya sereh.

Proses produksi minyak sereh

Proses pengambila minyak sereh dilakukan melalui proses penyulingan. Rendaman rata-rata minyak sereh sekitar $0,6-1,2 \%$, tergantung jenis sereh, serta penanganan dan efektifitas penyulingannya.

\section{Analisis Pembahasan}

Perkembangan bahan baku pada usaha minyak sereh di kecamatan masamba tahun 2006-2010.

Dalam sector kerajinan, bahan baku sebagai faktor produksi akan sangat menentukan produksi yang akan dihasilkan. Bila kita menggunakan bahan baku yang tepat, maka tentu akan menghasilkan produksi yang tinggi serta dengan kuatitas yang tinggi dan sangat memuaskan.

Untuk dapat mengetahui perkembangan bahan baku pada usaha minyak sereh di kecamatan masamba kabupaten luwu utara tahun 2006-2010.

\section{Penutup}

Kesimpulan dalam penelitian ini adalah: (a) Hasil analisa ragresi linear berganda dalam bentuk persamaan $\mathrm{Y}=4,53-3,03 \mathrm{X}_{1}+14,27 \mathrm{X}_{2}$. Interprestasi dari persamaan tersebut adalah sebagai berikut: (1) $b_{0}=4,53$ artinya apabila bahan baku $\left(X_{1}\right)$ dan tenaga kerja $\left(X_{2}\right)$, tidak ada atau bernilai nol, maka jumlah produksi minyak sereh bertambah sebesar 4,53 atau $5 \mathrm{~kg}$, (2) $\mathrm{b}_{1}=-3,03$ artinya bahan baku $\left(\mathrm{X}_{1}\right)$ mampu menambah 1 (satu) $\mathrm{kg}$, maka jumlah produksi minyak sereh akan menurun sebanyak 3,03 atau 3 botol dengan asumsi variabel tenega kerja tetap, (3) $b_{2}=14,27$ artinya apabila variabel tenaga kerja $\left(X_{2}\right)$, mengalami peningkatan 1 (satu) orang, maka jumlah produksi minyak sereh akan meningkat sebanyak 14,27 atau 14 botol dengan asumsi variabel bahan baku tetap, (b) Bahwa sistem pemesanan dan penyediaan bahan baku yang dijalankan perusahaan ini tepat, sehingga masih di butuhkan sistem pengendalian yang lebih baik untu menunjang kelancaran proses produksi. Adapun saran dari penelitian ini adalah: (a) Struktur ekonomi, khususnya di kecamatan masamba, maka industry kecil khususnya usaha minyak sereh perlu digalakkan dan dikelola dengan baik, (b) Peningkatan pengetahuan para pengusaha merupakan penentu kesuksesan dalam mengelola industry kecil, 
sehingga pembinaan dan pelatihan sebaiknya dilakukan secara intensif dikalangan para pengusaha.

\section{Daftar Pustaka}

Anonim. 1995, Pola Pembinaan Kepada Usaha Kecil Dan Koperasi PT. (Persero) Sucofindo, Jakarta.

Anonim. 1995, Undang - Undang Otonomi Daerah, Penerbit Kuraiko Pratama Bandung.

Assauri, Sofjan,. 1990, Manajemen Produksi, Edisi Ketiga, Jakarta Lembaga, Penerbit Fakultas Ekonomi Uneversitas Indonesia.

Irawan dan M. suparmoko. 1993, Ekonomi Pembangunan, BPFE Yogyakarta, Yogyakarta

Irsan Arsyad Saleh. 1991, Industri Kecil Sebuah Tinjauan Dan Perbandingan, LP3ES, Jakarta

Kotler, Philip (2002), Manajemen Pemasaran, Jilid I, Edisi Millennium, PT. Prebalindo, Jakarta 